\title{
Identification of Mutations in Antimalarial Resistance Gene Kelch13 from Plasmodium falciparum Isolates in Kano, Nigeria
}

\author{
Umar F. Abubakar ${ }^{1}$, Ruqayya Adam ${ }^{2}$, Muhammad M. Mukhtar ${ }^{3}{ }^{(}$, Abdullahi Muhammad $^{3,4}{ }^{(\mathbb{D}}$, \\ Adamu A. Yahuza ${ }^{5}$ and Sulaiman S. Ibrahim ${ }^{3,4, *(D)}$ \\ 1 Laboratory Department, Public Health and Diagnostic Institute, Yusuf Maitama Sule University, \\ Kwanar Dawaki, PMB 3220 Kano, Nigeria; farouqabu@nwu.edu.ng \\ 2 Department of Biological Sciences, Faculty of Sciences, Federal University Dutsinma, \\ PMB 5001 Katsina, Nigeria; radam@fudutsinma.edu.ng \\ 3 Department of Biochemistry, Bayero University, PMB 3011 Kano, Nigeria; \\ muhammadmahemukhtar@gmail.com (M.M.M.); Abdullahi.Muhammad@lstmed.ac.uk (A.M.) \\ 4 Vector Biology Department, Liverpool School of Tropical Medicine (LSTM), Liverpool L3 5QA, UK \\ 5 Department of Medical Microbiology and Parasitology, Faculty of Clinical Sciences, Bayero University, \\ PMB 3011 Kano, Nigeria; ayadamu.mpc@buk.edu.ng \\ * Correspondence: sulaimansadi.ibrahim@crid-cam.net; Tel.: +447440443871
}

Received: 29 March 2020; Accepted: 25 May 2020; Published: 27 May 2020

\begin{abstract}
Malaria control relies on first-line treatments that use artemisinin-combination therapies (ACT). Unfortunately, mutations in the plasmodium falciparum kelch13 gene result in delayed parasite clearance. Research on what is causing ACT failure is non-existent in northwestern Nigeria. Thus, the presence of mutations in kelch13 in P. falciparum isolates from Kano, Nigeria was investigated in this study. Microscopic examination of 154 blood samples obtained from patients revealed a high prevalence of $P$. falciparum infection (114 positive individuals, slide positivity rate $=74.03 \%$ ). The 114 patients were administered Cartef ${ }^{\circledR}(\mathrm{ACT})$ and out of the 50 patients that returned for the 14-day follow up, 11 were positive for P. falciparum (slide positivity rate $=22 \%$ ). On day 0,80 samples out of 114 and 11 samples on day 14 (91 out of 125 microscopy-positive samples) were positive with Plasmodium according to the PCR of cytochrome oxidase I, which corresponds to $72.8 \%$. A fragment of the kelch13 gene encompassing the propeller domains was sequenced in 49 samples, alongside samples of the susceptible strain $p f_{-} 3 \mathrm{D} 7$. Low polymorphism was observed, suggesting a lack of selection on this gene, and only six mutations (Glu ${ }^{433} \mathrm{Gly}$, Phe ${ }^{434} \mathrm{Ile}$, Phe ${ }^{434} \mathrm{Ser}$, Ile ${ }^{684} \mathrm{Asn}$, Ile ${ }^{684} \mathrm{Thr}$ and $\mathrm{Glu}^{688} \mathrm{Lys}$ ) were found. The epidemiologic impact of these mutations and their potential role in ACT resistance needs to be investigated further.
\end{abstract}

Keywords: artemisinin combination therapy; resistance; SNP; mutation; kelch13; P. falciparum; malaria

\section{Introduction}

Malaria still takes the lives of approximately 405,000 people every year, $93 \%$ of these are in Africa, of which Nigeria alone accounts for 25\% [1]. Malaria control relies heavily on vector control and administration of antimalarial medicines [2]. The use of antimalarials and vector control has contributed to a significant reduction in the malaria burden in Africa by about $40 \%$ from 2000 to 2015 [3]. Starting from 2005, the World Health Organization (WHO) recommended artemisinin combination therapy (ACT) as a first-line therapy for uncomplicated P. falciparum malaria, a policy that was adopted by many endemic countries [4]. Nigeria first adopted ACT drugs as a first-line treatment of uncomplicated P. falciparum in 2005 [5]. Currently, there are no alternative, fully effective 
first-line therapies available to replace ACT should artemisinin fail globally [6]. Unfortunately, ACT resistance, which was first discovered in the Greater Mekong Sub-Region [7] and is now widespread across the world [4], is threatening the progress made in malaria control. Several mutations, including N458Y, Y493H, R539T, I543T, and C580Y in the propeller domain of the kelch13 gene of Plasmodium falciparum were found to be associated with delayed parasite clearance following artemisinin treatment, as observed in Southeast Asia [8,9]. The kelch13 encodes 726 amino acids with a broad-complex, tram track, bric-a-brac/poxvirus and zinc finger (BTB/ POZ) domain and a C-terminal 6-blade propeller domain [8], where most mutations linked to delayed parasite clearance are found. However, most of the polymorphisms of the kelch13 gene that have been described in a few studies in Africa vary from those observed in Southeast Asia [10], with radical mutations common in Southeast Asia and the African mutations not undergoing strong selection [11]. Therefore, it is still not understood whether the mutation of this gene in the African parasite population correlates with selection induced by antimalarial usage [12]. Several studies have been conducted in African countries to establish the presence of the kelch13 mutations, and have led to the discovery of several mutations, for example, the non-synonymous mutations (M472I; Y558C; K563R; P570L; P615S) discovered in Niger [13], a novel mutation, R622I discovered in Ethiopia [14], 15 non-synonymous mutations in isolates from Senegal [15], and the P553L mutation reported in Mali, Kenya, and Malawi [16]. However, these mutations have not been linked to delayed parasite clearance. The main mutations linked to delayed parasite clearance and artemisinin resistance in the kelch13 gene, e.g., Y493H, C580Y and Y493H occur at a very low frequency across Africa [11]. Indeed, a recent metadata analysis by the WorldWide Antimalaria Resistance Network (WWARN) reported that kelch13 mutations in African sites remains at very low prevalence, generally below $3 \%$, and that there is still no evidence of slow-clearing parasites or selection for mutant parasites [17]. However, the emergence of indigenous artemisinin-resistant P. falciparum has been documented in Africa [18] and a mutation, A578S (observed at low-frequency) has been associated with prolonged parasite clearance in a study conducted in Uganda [19].

Recently, a study in southeastern Nigeria reported four synonymous substitutions at the propeller domain of the kelch13 gene that do not result in amino acid substitution and are not associated with delayed parasite clearance [20]. These types of studies on polymorphism in the kelch13 gene are hard to come by in northwestern Nigeria, where the bulk of the country's population lives. To contribute to malaria elimination efforts in northern Nigeria, single nucleotide polymorphisms (SNPs) and mutations in a kelch13 propeller gene in P. falciparum isolates from Kano was investigated. This established the presence of four mutations that have not been described elsewhere, two of these were from individuals that returned on the 14-day follow-up with infection.

\section{Materials and Methods}

\subsection{Sample Collection}

Patients $(18-56$ years, $\mathrm{n}=154)$ presenting with malaria at Murtala Muhammad Specialist Hospital and Nassarawa Hospital in the Kano metropolis were recruited for this research. Younger individuals and pregnant women in their first trimester were excluded. Ethical clearance (MOH/Off/797/T.I./402) for sample collection was provided by the Ethics Sub-Committee of Health Operational Research Unit, Ministry of Health, Kano State, Nigeria.

Blood samples were collected on 24-25 August 2018 by standard venipuncture without undue pressure, either on the arm or syringe. Thick and thin blood films were prepared on clean, grease-free glass slides, and $3 \mathrm{ml}$ of the whole blood was dispensed into ethylenediaminetetraacetic acid (EDTA) anticoagulated containers. The blood samples were screened for the presence of malaria parasite using Geimsa staining microscopy [21] at both of the hospitals. Samples were then transferred on ice to the Department of Biochemistry, Bayero University, Kano (BUK) for molecular analysis. 


\subsection{Drug Treatment and Follow Up}

On the day of the first sample collection (day 0), 114 patients were identified as infected with P. falciparum using thick and thin blood film microscopy. Microscopic examination of slides from the rest of the patients (forty individuals) revealed no infection of any of the four major human malaria parasites. The 114 patients infected with Plasmodium were provided with ACT, Cartef ${ }^{\circledR}$ (GB PHARMA, United Kingdom), an Artemether/Lumefantrin ( $80 \mathrm{mg} / 480 \mathrm{mg}$ taken twice daily). The dangers of non-compliance with the drug regimen was explained in detail to all patients. Parasite clearance was evaluated after 14 days of drug therapy in the 50 individuals that returned for follow-up, by blood collection and microscopy (conducted independently in the hospitals and BUK). The positive samples from the microscopy at day 0 (114 individuals) and those from the 14-days after treatment (50 individuals returned and 11 of them were still infected with P. falciparum) were used for downstream molecular analyses.

\subsection{DNA Extraction and Confirmation of Plasmodium Falciparum Infection Using PCR}

DNA was extracted from the whole blood of 125 patients who were positive for P. falciparum. These included all 114 samples collected at day 0 , and the 11 positive samples from follow up. DNA isolation was carried out using the QIAamp ${ }^{\circledR}$ DNA Mini Kit (QIAGEN, Hilden, Germany) according to the manufacturer's instructions. DNA pellet from an antimalarial susceptible parasite strain, 3D7 was provided by Dr Janet Storm from the Parasitology Department, LSTM, UK and used alongside the field samples for DNA extraction. The DNA was eluted in $100 \mu \mathrm{L}$ of nuclease-free water and its concentration measured using the Qubit 4.0 fluorometer (Invitrogen, Massachusetts, USA). Samples were stored at $-20^{\circ} \mathrm{C}$.

Due to the drawbacks of Plasmodium microscopy (false positives associated with artifacts and contaminants) [21,22], the direct PCR method as described by Echeverry et al. [23] was used to confirm infection. Primers, CoxI-F 5'-agcggttaacctttcttttccttacg-3' and CoxI-R (5'-agtgcatcatgtatgacagcatgtt-3') targeting the cytochrome oxidase I (COX I) subunit of Plasmodium species was used for the PCR. Briefly, $1 \mu \mathrm{L}$ each of genomic DNA, $1.5 \mu \mathrm{L}$ of $10 \times$ TaqA Buffer, $0.4 \mu \mathrm{M}(0.5 \mu \mathrm{L})$ each of forward and reverse primers, $0.63 \mathrm{mM}(0.375 \mu \mathrm{L})$ of $\mathrm{MgCl}_{2}, 0.4 \mathrm{mM}(0.24 \mu \mathrm{L})$ of dNTP mixes, $0.2 \mu \mathrm{L}$ of Taq DNA polymerase

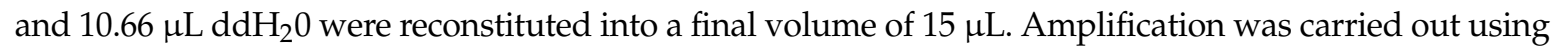
the following cycling conditions: initial denaturation at $95^{\circ} \mathrm{C}$ for $3 \mathrm{~min}$, followed by 35 cycles each of $1 \mathrm{~min}$ at $94{ }^{\circ} \mathrm{C}$ (denaturation), $1 \mathrm{~min}$ at $62^{\circ} \mathrm{C}$ (primer annealing), and $1 \mathrm{~min}$ at $72{ }^{\circ} \mathrm{C}$ (extension). This was followed with a $10 \mathrm{~min}$ final extension at $72{ }^{\circ} \mathrm{C}$. PCR products were separated in a $1.5 \%$ agarose gel stained with pEqGREEN (GeneOn, Leicestershire, England) and visualized using Ingenius 3 Gel Doc (Syngene, Cambridge, UK).

\subsection{Amplification of Propeller Domains of the Kelch13 Gene and Column Purification}

The DNA samples were used to amplify a fragment of the kelch13 gene encompassing the propeller domain, based on the nested PCR protocol of Ariey et al. [8] with modifications in the kelch-in primers and thermocycling conditions. In the first round PCR, primers kelch-out-F ( $5^{\prime}$-gggaatctggtggtaacagc $\left.-3^{\prime}\right)$ and kelch-out-R ( $5^{\prime}$-cggagtgaccaaatctggga- $\left.3^{\prime}\right)$ were used. PCR was carried out in a $20 \mu \mathrm{L}$ final volume comprised of $2 \mu \mathrm{L}$ of the genomic DNA, $10 \mu \mathrm{L}$ of a GoTaq master mix (Promega, Wisconsin, USA) containing optimized buffer, $\mathrm{MgCl}_{2}$ and dNTP mixes; $1 \mu \mathrm{L}$ each of forward and reverse primers and $6 \mu \mathrm{L} \mathrm{ddH_{2 }} 0$. Thermocycling conditions were initial denaturation at $95{ }^{\circ} \mathrm{C}$ for $1 \mathrm{~min}$, followed by 35 cycles each of $20 \mathrm{sec}$ at $95{ }^{\circ} \mathrm{C}$ (denaturation), $20 \mathrm{sec}$ at $57^{\circ} \mathrm{C}$ (primer annealing), $1.5 \mathrm{~min}$ at $60^{\circ} \mathrm{C}$ (extension). This was followed with a 3 min final extension at $60^{\circ} \mathrm{C}$. PCR products were separated in $1.5 \%$ agarose gel stained with pEqGREEN and visualized for bands. For nested PCR, primers kelch-in-F2 ( $5^{\prime}$ - cataccaaaagatttaagtgaaagtgaagc $\left.-3^{\prime}\right)$ and the kelch-out-R (above) were used. PCR was carried out in a final volume of $20 \mu \mathrm{L}$ comprised of $2 \mu \mathrm{L}$ of the genomic DNA, $10 \mu \mathrm{L}$ of master mix (Promega, Wisconsin, USA), $1 \mu \mathrm{L}$ each of forward and reverse primers and $6 \mu \mathrm{L}$ of $\mathrm{ddH}_{2} \mathrm{O}$. Amplification 
was carried out using the following conditions: initial denaturation at $95{ }^{\circ} \mathrm{C}$ for $1 \mathrm{~min}$, followed by 35 cycles each of $20 \mathrm{sec}$ at $95^{\circ} \mathrm{C}$ (denaturation), $20 \mathrm{sec}$ at $57^{\circ} \mathrm{C}$ (primer annealing), $1 \mathrm{~min}$ at $60{ }^{\circ} \mathrm{C}$ (extension). This was followed with a $3 \mathrm{~min}$ final extension at $60^{\circ} \mathrm{C}$. PCR products were separated in a $\%$ agarose gel stained with pEqGREEN and examined for bands. The nested PCR products were purified using the QIAquick ${ }^{\circledR}$ PCR Purification Kit (QIAGEN, Hilden, Germany) and DNA eluted in $30 \mu \mathrm{L}$ of nuclease-free water.

\subsection{Cloning of the Kelch13 Fragment and Sequencing}

The purified nested products were ligated into pJET1.2 (CloneJET PCR Kit, ThermoFisher Scientific, UK) vector according to the manufacturer's instruction. Ligated products were transformed into DH5 $\alpha$ E. coli cells (Promega, Wisconsin, USA) by mixing $4 \mu \mathrm{L}$ of the purified nested products to $40 \mu \mathrm{L}$ of the cells pre-chilled on ice. This was incubated on ice for $30 \mathrm{~min}$ followed by heat shocking for $45 \mathrm{sec}$ at $42{ }^{\circ} \mathrm{C}$. Transformants were returned to ice and chilled for $2 \mathrm{~min}$ before $950 \mu \mathrm{L}$ of S.O.C medium was added. Transformants were incubated for $1 \mathrm{~h}$ at $37^{\circ} \mathrm{C}$ and $200 \mathrm{rpm}$. Then, $100 \mu \mathrm{L}$ of the transformants were streaked onto LB plates containing $100 \mathrm{mg} / \mathrm{mL}$ ampicillin and incubated at $37^{\circ} \mathrm{C}$ overnight. Colonies that had grown in the plates were individually picked and diluted in $20 \mu \mathrm{L}$ $\mathrm{ddH}_{2} \mathrm{O}$ and used for colony PCR. Primers, pJET1.2-F (5'-cgactcactatagggagagcggc-3') and pJET1.2-R (5-aagaacatcgatttccatggcag-3') were used in PCR to identify positive colonies. $1.5 \mu \mathrm{L}$ of $10 \times$ Taq A buffer, $2 \mu \mathrm{L}$ of $\mathrm{dNTP}$ mixes, $0.75 \mu \mathrm{L}$ of $2 \mathrm{mM} \mathrm{MgCl}_{2}, 0.4 \mu \mathrm{L}$ each of above primers, $0.1 \mu \mathrm{L}$ of KAPATaq polymerase and $13.9 \mu \mathrm{L}$ of $\mathrm{ddH}_{2} 0$ were constituted into a final volume of $19 \mu \mathrm{L}$. Then, $1 \mu \mathrm{L}$ of colony suspended in $\mathrm{ddH}_{2} \mathrm{O}$ was added to this and PCR was carried out with the following conditions: initial denaturation at $95^{\circ} \mathrm{C}$ for $3 \mathrm{~min}$, followed by 35 cycles each of $30 \mathrm{sec}$ at $94{ }^{\circ} \mathrm{C}$ (denaturation), $30 \mathrm{sec}$ at $60{ }^{\circ} \mathrm{C}$ (primer annealing), $1.5 \mathrm{~min}$ at $72{ }^{\circ} \mathrm{C}$ (extension). This was followed with $5 \mathrm{~min}$ final extension at $72{ }^{\circ} \mathrm{C}$. PCR products were separated in a $1.5 \%$ agarose gel as described above. Positive colonies were mini-prepped overnight. Positive colony $(4 \mu \mathrm{L})$ in $\mathrm{ddH}_{2} \mathrm{O}$ and $4 \mu \mathrm{L}$ of $100 \mathrm{mg} / \mathrm{mL}$ ampicillin were added into a $15 \mathrm{~mL}$ tube containing $6 \mathrm{ml}$ of LB medium. Tubes were incubated at $37^{\circ} \mathrm{C}$ and $200 \mathrm{rpm}$ for $14 \mathrm{~h}$ and $4.5 \mathrm{~mL}$ of overnight culture pelleted at $13000 \mathrm{rpm}$ for $10 \mathrm{~min}$. Plasmid preparation was carried out using the QIAprep ${ }^{\circledR}$ Spin Miniprep Kit (QIAGEN, Hilden, Germany) and the plasmid concentration was measured using a Nanodrop spectrophotometer (Thermo Fisher Scientific, Massachusetts, USA). Plasmids were sequenced using the pJET1.2-F and pJET1.2-R primers mentioned above.

\subsection{Analysis of Genetic Variability of Kelch13}

Polymorphism analysis of sequences was carried out through manual examination of the sequence traces using Bioedit version 7.2.3.0 [24] and/or nucleotides/amino acid differences from multiple sequence alignments with the CLC sequence viewer v7.6 (http://www.clcbio.com/). Genetic parameters such as the number of haplotypes $(\mathrm{h})$ and its diversity $(\mathrm{Hd})$, the number of polymorphic sites $(\mathrm{S})$ and nucleotide diversity $(\pi)$ were computed using DnaSP 5.10 [25]. Different haplotypes were compared by constructing a maximum likelihood phylogenetic tree, using MEGA 6.06 [26].

\section{Results}

\subsection{Malaria Slide Positivity Rate}

From 154 suspected malaria patients recruited on day 0,114 were positive for P. falciparum (74.03\%) (Table 1). Analysis of samples from 50 patients who returned for the 14-day follow up (out of the 114 patients that were given Carte ${ }^{\circledR}$ ) found that 11 of these patients were still infected with $P$. falciparum (day-14 slide positivity $=22.0 \%$ ). Infection in these samples was confirmed with PCR and they were then used along with the initial 114 patients from day 0 , making a total of 125 samples for downstream molecular analyses. 
Table 1. Summary of malaria parasite microscopy.

\begin{tabular}{cccc}
\hline Day of Treatment & No. of Positive & No. of Negative & Total No. of Samples \\
\hline Day 0 & $114(74.0 \%)$ & $40(26.0 \%)$ & $154(100 \%)$ \\
\hline Day 14 (Follow Up) & $11(22.0 \%)$ & $39(78.0 \%)$ & $50(100 \%)$ \\
\hline Total & 125 & 79 & 204
\end{tabular}

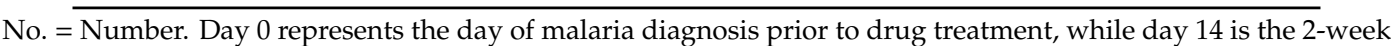

follow up day after initiating drug treatment, to evaluate parasitemia after drug administration.

\subsection{Cytochrome Oxidase III PCR Confirmation of Plasmodium Infection}

Out of the 125 samples used for PCR, only 91 samples (72.8\%) were confirmed as positive for P. falciparum/P. vivax (Figure 1).

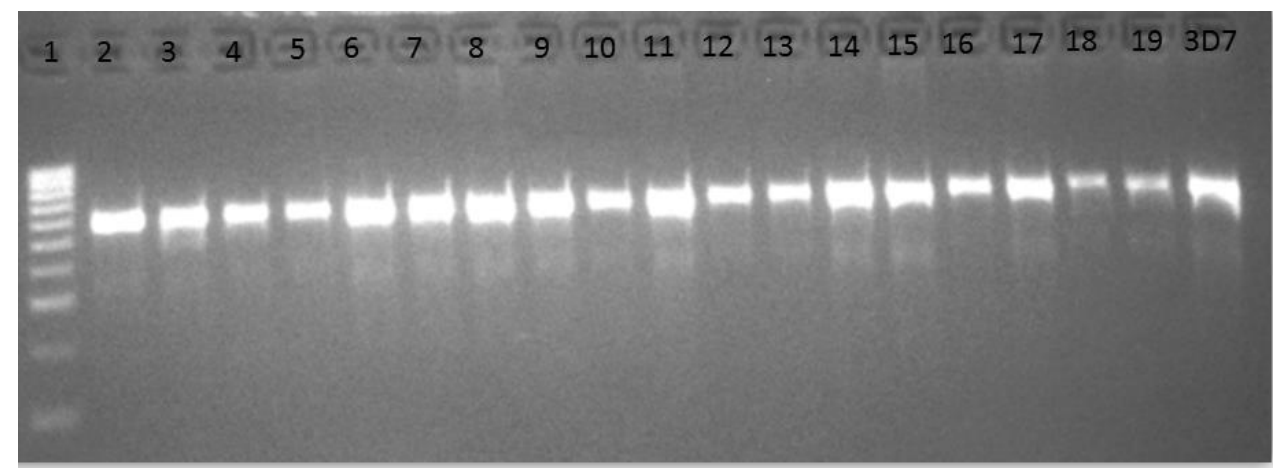

Figure 1. Cytochrome oxidase I (COX I) PCR confirmation of Plasmodium infection. Lane $1=$ Molecular ladder (Hyper ladder IV: 50-1013 bp, Bioline), lanes 2-19 = 540 bp representing COX I gene of malaria parasite. Lane 20 is the band from the 3D7 reference susceptible strain.

\subsection{Amplification and Cloning of the Kelch13 Fragment}

In first round PCR, DNA from 91 samples was used to successfully amplify fragment of kelch13 gene, with PCR products of 2097 bp (Figure 2a). These include 80 of the 82 day 0 samples that were positive for Plasmodium from the PCR, plus the DNA from 11 follow-up samples.

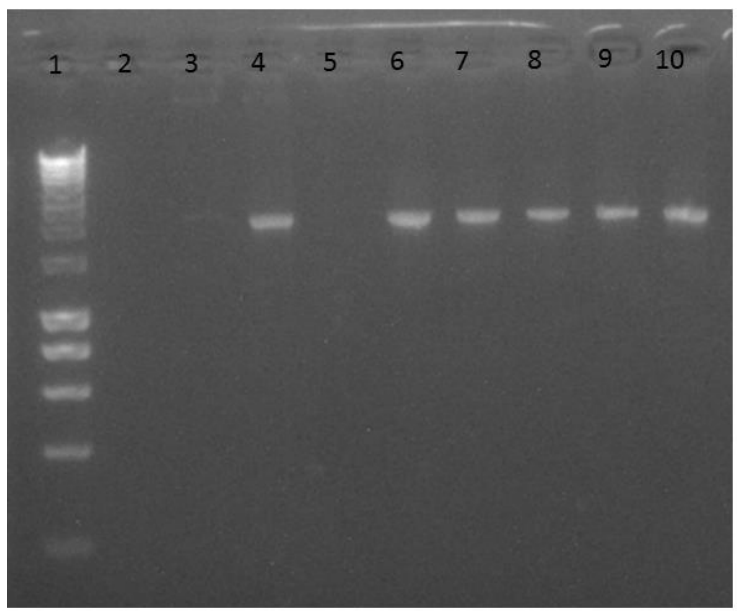

(a)

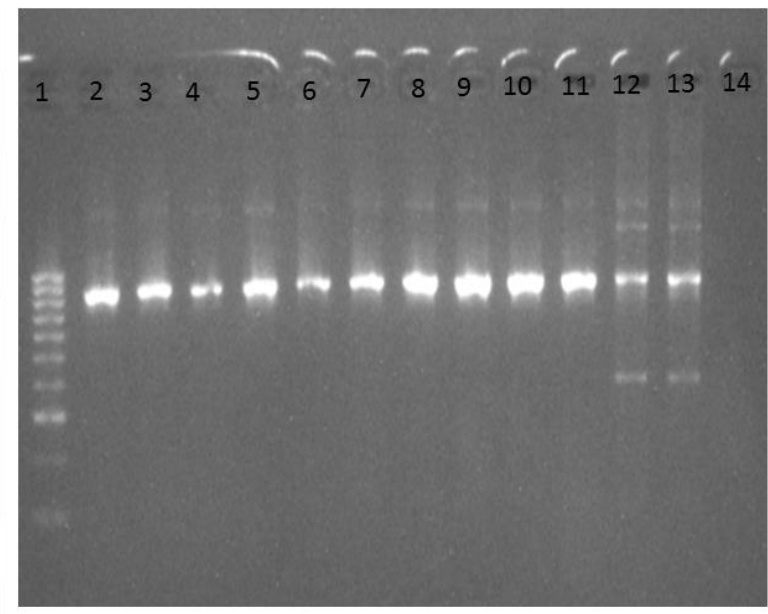

(b)

Figure 2. Agarose gel of PCR for amplification of kelch13 fragments. (a) first round PCR, lane 1 = molecular ladder (Hyper ladder $1200 \mathrm{bp}-10 \mathrm{~kb}$, Bioline); lanes 3, 4, 6, 7, 8, and 9 represent samples 
from malaria-infected individuals with 2097 bp fragment. Lane $10=3$ D7 reference susceptible Plasmodium strain; lane 2 is negative control with no DNA and lane 5 is example of sample that failed; (b) nested PCR, lane 1 = molecular ladder (Hyper ladder IV, 50-1013 bp, Bioline), lanes 2-12 = band size of $849 \mathrm{bp}$, corresponding to kelch13 propeller domain of Plasmodium isolates; lane 13 = 3D7 and lane 14 is negative control with no DNA. Non-specific bands were seen in the samples in lanes 12 and 13. Note: the samples in panel $2 \mathrm{a}$ and $2 \mathrm{~b}$ are not correlated.

From nested PCR, 2849 bp fragments corresponding to nucleotides 1281-2129 (which covers almost the entire sequence of the Broad complex tram track bric a brac (BTB) and six blades of propeller domains, codons 427-709) were amplified successfully in 77 samples (Figure 2b). Because of the non-specific bands that were observed in some samples, e.g., in lanes 12 and 13 in Figure 2b, the 77 nested PCR products were purified and successfully cloned into E. coli DH5 $\alpha$ to confirm sizes using PCR. Positive colonies were mini-prepped and 50 samples were sequenced.

\subsection{Pattern of Genetic Variability of the Kelch13 Fragment}

Out of the 77 purified nested PCR products, 50 were successfully sequenced. These comprised 49 field samples and a fragment amplified from the pf_3D7. The 49 field samples comprised seven samples from the follow-up individuals and 42 samples from day 0. Analyses of all sequences revealed eight mutations compared to the pf_3D7 sequences (Table 2). These sequences have been deposited into the Genbank with accession numbers: MT263314-MT263363. Two isolates; MM_12B and MM_83B from the 14-day follow up harbor Glu ${ }^{433}$ Gly and Glu ${ }^{688}$ Lys, mutations, respectively. These mutations are not seen in the other day 0 isolates or the other five samples from follow up. In addition, the other four non-synonymous mutations include Phe ${ }^{434}$ Ile obtained from day 0 isolates MM_31 and MM_21, as well as Phe ${ }^{434}$ Ser, Ile ${ }^{684}$ Asn, Ile ${ }^{684} \mathrm{Thr}$, which were present only in the day 0 isolates MM_114, MM_10 and NSR_59, respectively.

Table 2. Polymorphisms observed in the kelch13 fragments and amino acid substitutions.

\begin{tabular}{|c|c|c|c|c|c|c|c|}
\hline $\begin{array}{l}\text { Domain/ } \\
\text { Propeller }\end{array}$ & $\begin{array}{l}\text { Wild Type } \\
\text { Codon }\end{array}$ & $\begin{array}{l}\text { Polymorphic } \\
\text { Site }\end{array}$ & $\begin{array}{l}\text { Position } \\
\text { (nt) }\end{array}$ & $\begin{array}{l}\text { Observed } \\
\text { Mutation }\end{array}$ & $\begin{array}{c}\text { Sequence (s) } \\
\text { with Mutation }\end{array}$ & $\begin{array}{c}\text { Substitution } \\
\text { Type }\end{array}$ & $\begin{array}{c}\text { Day of } \\
\text { Collection }\end{array}$ \\
\hline BTB/POZ & GAAA & GGA & 1298 & Glu $^{433}$ Gly & 1 (MM_12B) & NS & 14th \\
\hline $\mathrm{BTB} / \mathrm{POZ}$ & $\underline{\text { TTT }}$ & $\underline{\text { ĀTT }}$ & 1300 & $\mathrm{Phe}^{434}$ Ile & $\begin{array}{l}\text { 2(MIM_31, } \\
\text { MM_21) }\end{array}$ & NS & 0 \\
\hline $\mathrm{BTB} / \mathrm{POZ}$ & TTT & $\mathrm{T} \underline{\mathrm{CT}}$ & 1301 & Phe ${ }^{434}$ Ser & 1 (MM_114) & NS & 0 \\
\hline Blade 1 & TTT & TTC & 1325 & Phe ${ }^{442}$ Phe & 1 & $S$ & 0 \\
\hline Blade 2 & TTT & TTC & 1473 & Phe ${ }^{492}$ Phe & 1 & $S$ & 0 \\
\hline Blade 6 & ATT & AAT & 2051 & $\mathrm{Ile}^{684}$ Asn & 1 (MM_10) & NS & 0 \\
\hline Blade 6 & ATT & $\mathrm{AC} \underline{\mathrm{T}}$ & 2051 & $\mathrm{Ile}^{684} \mathrm{Thr}$ & 1 (NSR_59) & NS & 0 \\
\hline Blade 6 & GAA & $\underline{\mathrm{AAA}}$ & 2062 & $\mathrm{Glu}^{688}$ Lys & 1 (MM_83B) & NS & 14th \\
\hline
\end{tabular}

BTB/POZ; Broad complex tram track bric a brac/poxvirus zinc finger, nt; nucleotide; No.: Number; Glu: Glutamic acid; Gly: Glycine; Phe: Phenylalanine; Ile: Isoleucine; Ser: Serine; Asn: Asparagine; Thr: Threonine; Lys: Lysine.

Six of these mutations are non-synonymous (NS): Glu ${ }^{433} \mathrm{Gly}$, Phe ${ }^{434} \mathrm{Ile}, \mathrm{Phe}^{434}$ Ser, $\mathrm{Ile}^{684} \mathrm{Asn}$, $\mathrm{Ile}^{684} \mathrm{Thr}$ and $\mathrm{Glu}^{688}$ Lys. The first three mutations are in the BTB/POZ domain and the last three are in the 6th blade of the propeller domain (Figure 3).

From the 49 samples sequenced, the kelch13 was discovered not to be highly polymorphic. It has nine haplotypes (Table 3) with haplotype diversity, Hd of only 0.336 . The sequences possess eight polymorphic sites (S); two of which were synonymous and six led to amino acids substitution. A neutrality test of all the sequences revealed $\mathrm{Li}$ and $\mathrm{Fu}^{\prime} \mathrm{S} \mathrm{D}^{*}$ as negative and statistically significant, which indicates an excess of singleton mutations. The Tajima D statistic, on the other hand shows a low frequency of polymorphism. Overall, the presence of a dominant haplotype and very low diversity, 
with most mutations being non-synonymous suggests that this gene is either probably undergoing selection, or these mutations are just rare and endogenous.

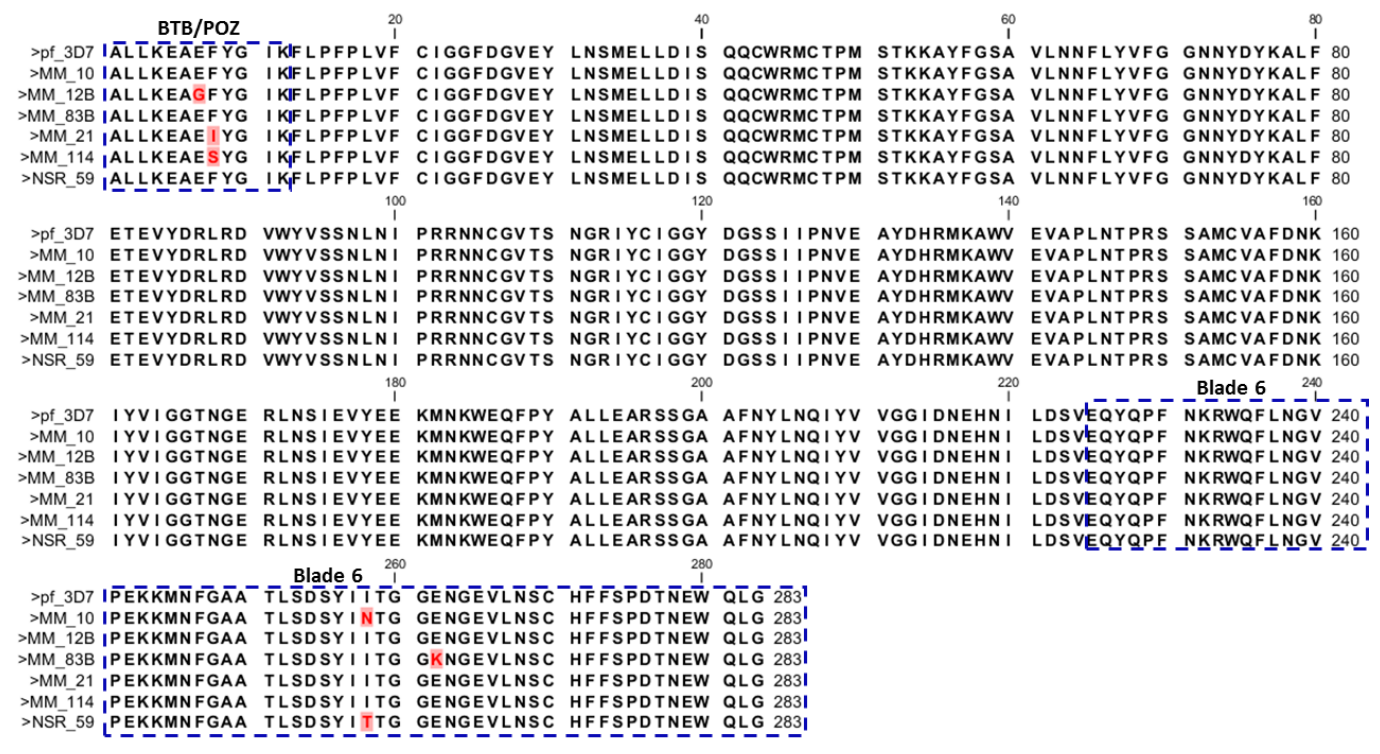

Figure 3. Comparison of amino acid sequences from field isolates with the amino acids of Pf_3D7 sequence. Residues with mutations are in red and highlighted. MM_83B and MM_12B are sequences from isolate of patients that responded to the 14-day follow up and were still infected with Plasmodium. Nucleotide positions were compared to the description in the literature: 350-442, BTB/POZ, 442-475; blade 1475-527; blade 2527-574; blade 3574-614; blade 4614-666; blade 5666-727, blade 6. Different amino acids are in red and highlighted in pink.

Table 3. Summary statistics for polymorphism of fragment of kelch13 gene in P. falciparum isolates from Kano.

\begin{tabular}{ccccccccc}
\hline $\mathbf{N}$ & $\mathbf{S}$ & $\mathbf{H}$ & $\mathbf{H}_{\mathbf{d}}$ & $\mathbf{S y n}$ & Nonsyn & $\boldsymbol{\pi}(\mathbf{k})$ & $\mathbf{D}$ (Tajima) & $\mathbf{D}^{*}$ (Fu and Li) \\
\hline 49 & 8 & 9 & 0.336 & 2 & 6 & $0.00043(0.364)$ & $-2.18234^{\text {sig }}$ & $-3.67210^{\text {sig }}$ \\
\hline
\end{tabular}

$\mathrm{N}$; number of sequences; $\mathrm{S}$, number of polymorphic sites; h, haplotype; $\mathrm{H}_{\mathrm{d}}$, haplotype diversity; Syn, Synonymous mutations; Nonsyn, Non-synonymous mutations; $\pi$, nucleotide diversity ( $\mathrm{k}=$ mean number of nucleotide differences); Tajima's D and Fu and Li's D statistics; ns, not significant; sig, significant.

A predominant haplotype, which had the largest frequency was observed (Figure 4a). This haplotype 1 is comprised of 40 sequences out of 49 . It was followed by haplotype 8 with two sequences, while the rest of the haplotypes have only one sequence each. Figure $4 \mathrm{~b}$ presents the position of the nucleotide substitution, respectively, with respect to the predominant haplotype 1.

To establish genetic distances, a phylogenetic tree was constructed with the 49 sequences successfully sequenced and a sequence of pf_3D7 (Figure 4c). Sequences cluster according to the presence of mutation, with the sequences harboring mutations clustering away from sequences of the Hap_1 and that of the pf_3D7. 
(a) Hap \# Freq. Sequences

Hap_1: 40 MM1-15, 17-39, 41-42

Hap_2: 1 NSR75

Hap_3: 1 MM17

Hap_4: 1 MM12B

Hap 5: 1 MM114

Hap_6: 1 MM83B

Hap 7: 1 MM10

Hap_8: 2 MM21, MM31

Hap_9: 1 NSR59

(b) $\quad 1111122$

2333400

9002756

8015312

Hap_1 ATTCCTG

Hap_2 ... T. .

Hap_3 .... T. .

Hap_4 G.....

Hap_5 ... C ...

Hap_6 ...... A

$\mathrm{Hap}^{7} 7 \ldots . . . A$

Hap_8 . A .....

Hap_9 ..... C

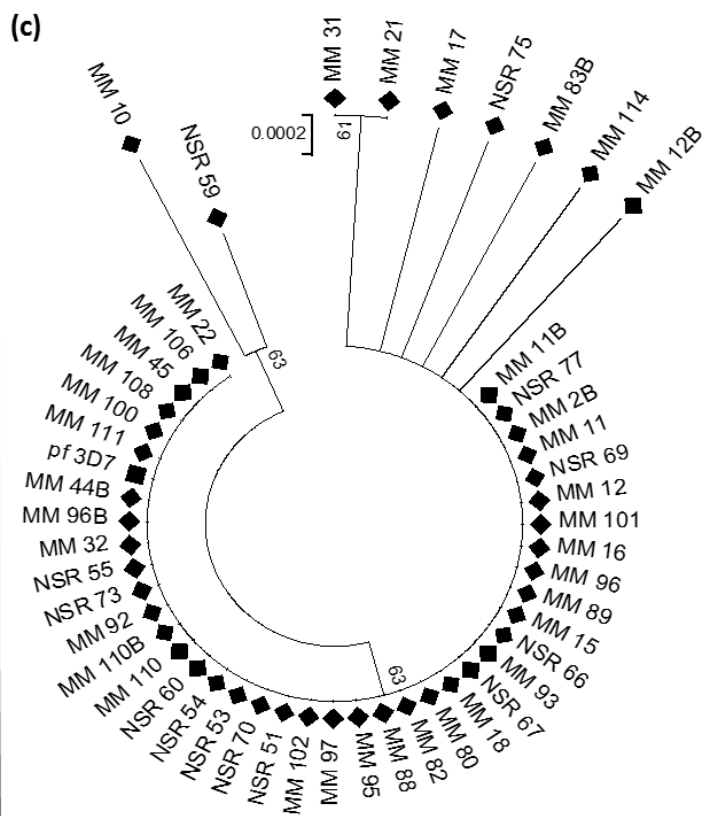

Figure 4. Genetic variability of fragments of kelch13 gene. (a) Summary of haplotype frequencies; (b) nucleotide substitution positions; and (c) a maximum likelihood phylogenetic tree of sequences with all field sequences presented in a diamond shape and the sequence from pf_3D7 in a block square.

\section{Discussion}

This study investigated the presence of polymorphism in the kelch13 gene using P. falciparum isolates from northern Nigeria. Eight polymorphic sites were discovered in the propeller region of this gene, with six of them leading to amino acids substitution. However, none of the four most implicated mutations associated with ACT resistance (Y493H, R539T, I543T, or C580Y) [8] were seen in the field isolates from Kano. Indeed, the absence of these mutations has been reported previously in southeastern Nigeria and other African countries, including Niger, Cameroon and Benin, that share borders with Nigeria [20,27]. However, several other mutations exist across the propeller domain of the kelch13 gene in sub-Saharan African P. falciparum isolates, with 22 major non-synonymous mutations already described. These include A557S, V566I, A569T, S576L, A578S, L589I, with the A578S being the most common $[16,28,29]$. None of these mutations were found in the field isolates investigated in this study. In Senegal, N554H, Q613H and V637I were reported [30] and recently in the Niger Republic, five mutations (M472I, Y558C, K563R, P570L and P615S) were also described in the propeller domain of kelch13 gene [27]. However, none of these mutations was detected in any of our isolates, despite the geographic closeness between the Niger Republic and Kano, in northern Nigeria. Several other mutations observed in other African countries include the most frequent mutation in Mali, F446I [31] and a few synonymous mutations reported in Burkina Faso [32]. None of these mutations were found in samples from Kano. The mutations observed in the Kano isolates may be unique to the Sudan/Sahel of northwest Nigeria. The high heterogeneity in the kelch13 gene mutations across sub-Saharan Africa suggests lack of selection in this gene. The results of microscopy strengthen previous observations of $P$. falciparum being the primary parasite responsible for malaria in northern Nigeria. Previous studies in Nigeria show similar results, for example, in southwestern Nigeria, where malaria parasite positivity was found among $61.1 \%$ of the study population [33]. Similarly, a $73.39 \%$ prevalence was also documented in another study in southeast of Nigeria [34]. 


\section{Conclusions}

This study confirmed a high prevalence of falciparum malaria in Kano, northwestern Nigeria. As established in various previous studies, it was found that microscopy could lead to false positives and its result should be treated with caution. The kelch13 gene in P. falciparum isolate from Kano carries some novel mutations that should be further studied to establish their epidemiologic impact on antimalarial resistance.

Author Contributions: Conceptualization, S.S.I.; Formal analysis, S.S.I.; Investigation, U.F.A., R.A., M.M.M., A.M., A.A.Y. and S.S.I.; Methodology, U.F.A., M.M.M. and S.S.I.; Project administration, S.S.I.; Resources, S.S.I.; Supervision, S.S.I.; Validation, U.F.A. and S.S.I.; Visualization, S.S.I.; Writing-original draft, U.F.A.; Writing-review \& editing, R.A., M.M.M., A.A.Y. and S.S.I. All authors have read and agreed to the published version of the manuscript.

Funding: This research and associated costs of publishing were privately sponsored by SSI and UFA.

Acknowledgments: Authors are grateful to the Wellcome Trust (https://wellcome.ac.uk/). Equipment used for the molecular analyses was from grant number WT201918/Z/16/Z to SSI.

Conflicts of Interest: The authors declare no conflict of interest.

Ethical Approval: All subjects gave their informed consent for inclusion before they participated in the study. The study was conducted in accordance with the Declaration of Helsinki, and protocol approved. Clearance for sample collection was granted by the Operational Research Advisory Committee, Ministry of Health, Kano state, Nigeria (reference number MOH/off/797/TI/402).

\section{References}

1. WHO. World Malaria Report 2019; 9241565721; World Health Organization: Geneva, Switzerland, 2019.

2. WHO. World Malaria Report; World Health Organization: Geneva, Switzerland, 2011.

3. Bhatt, S.; Weiss, D.J.; Cameron, E.; Bisanzio, D.; Mappin, B.; Dalrymple, U.; Battle, K.E.; Moyes, C.L.; Henry, A.; Eckhoff, P.A.; et al. The effect of malaria control on Plasmodium falciparum in Africa between 2000 and 2015. Nature 2015, 526, 207-211. [CrossRef] [PubMed]

4. Ashley, E.A.; Dhorda, M.; Fairhurst, R.M.; Amaratunga, C.; Lim, P.; Suon, S.; Sreng, S.; Anderson, J.M.; Mao, S.; Sam, B.; et al. Spread of artemisinin resistance in Plasmodium falciparum malaria. N. Engl. J. Med. 2014, 371, 411-423. [CrossRef] [PubMed]

5. FMoH. National Antimalarial Treatment Guidelines Policy Federal Ministry of Health, National Malaria and Vector Control Division; Federal Ministry of Health: Abuja-Nigeria, Nigeria, 2005.

6. WHO. World Malaria Report 2014; World Health Organisation: Geneva, Switzerland, 2015.

7. WHO. World Malaria Report; World Health Organisation: Geneva, Switzerland, 2017; ISBN 978-92-4-156552-3.

8. Ariey, F.; Witkowski, B.; Amaratunga, C.; Beghain, J.; Langlois, A.-C.; Khim, N.; Kim, S.; Duru, V.; Bouchier, C.; Ma, L.; et al. A molecular marker of artemisinin-resistant Plasmodium falciparum malaria. Nature 2013, 505, 50-55. [CrossRef] [PubMed]

9. Daily, J.P. K13-Propeller Mutations and Malaria Resistance. N. Engl. J. Med. 2016, 374, 2492-2493. [CrossRef] [PubMed]

10. Menard, D.; Khim, N.; Beghain, J.; Adegnika, A.A.; Alam, M.S.; Amodu, O.; Rahim-Awab, G.; Barnadas, C.; Berry, A.; Boum, Y.; et al. A Worldwide Map of Plasmodium falciparum K13-Propeller Polymorphisms. N. Engl. J. Med. 2016, 374, 2453-2464. [CrossRef] [PubMed]

11. MalariaGEN Plasmodium falciparum Community Project. Genomic epidemiology of artemisinin resistant malaria. eLife 2016, 5, 17. [CrossRef]

12. Balikagala, B.; Mita, T.; Ikeda, M.; Sakurai, M.; Yatsushiro, S.; Takahashi, N.; Tachibana, S.-I.; Auma, M.; Ntege, E.H.; Ito, D.; et al. Absence of in vivo selection for K13 mutations after artemether-lumefantrine treatment in Uganda. Malar. J. 2017, 16, 23. [CrossRef]

13. Laminou, I.M.; Lamine, M.M.; Mahamadou, B.; Ascofare, O.M.; Dieye, A. Polymorphism of pfk13-propeller in Niger: Detection of Novel Mutations. J. Adv. Med. Med. Res. 2017, 22, 1-5. [CrossRef]

14. Bayih, A.G.; Getnet, G.; Alemu, A.; Getie, S.; Mohon, A.N.; Pillai, D.R. A Unique Plasmodium falciparum Kelch 13 Gene Mutation in Northwest Ethiopia. Am. J. Trop. Med. Hyg. 2016, 94, 132-135. [CrossRef] 
15. Talundzic, E.; Ndiaye, Y.D.; Deme, A.B.; Olsen, C.; Patel, D.S.; Biliya, S.; Daniels, R.; Vannberg, F.O.; Volkman, S.K.; Udhayakumar, V.; et al. Molecular Epidemiology of Plasmodium falciparum kelch13 Mutations in Senegal Determined by Using Targeted Amplicon Deep Sequencing. Antimicrob. Agents Chemother. 2017, 61, e02116-16. [CrossRef]

16. Taylor, S.M.; Parobek, C.; DeConti, D.K.; Kayentao, K.; Coulibaly, S.O.; Greenwood, B.M.; Tagbor, H.; Williams, J.; Bojang, K.A.; Njie, F.; et al. Absence of putative artemisinin resistance mutations among Plasmodium falciparum in Sub-Saharan Africa: A molecular epidemiologic study. J. Infect. Dis. 2014, 211, 680-688. [CrossRef]

17. WWARN K13 Genotype-Phenotype Study Group; Amaratunga, C. Association of mutations in the Plasmodium falciparum Kelch13 gene (Pf3D7_1343700) with parasite clearance rates after artemisinin-based treatments-A WWARN individual patient data meta-analysis. BMC Med. 2019, $17,1$. [CrossRef]

18. Lu, F.; Culleton, R.; Zhang, M.; Ramaprasad, A.; Von Seidlein, L.; Zhou, H.; Zhu, G.; Tang, J.; Liu, Y.; Wang, W.; et al. Emergence of Indigenous Artemisinin-Resistant Plasmodium falciparum in Africa. N. Engl. J. Med. 2017, 376, 991-993. [CrossRef]

19. Hawkes, M.T.; Conroy, A.L.; Opoka, R.O.; Namasopo, S.; Zhong, K.; Liles, W.C.; John, C.C.; Kain, K. Slow Clearance of Plasmodium falciparum in Severe Pediatric Malaria, Uganda, 2011-2013. Emerg. Infect. Dis. 2015, 21, 1237-1239. [CrossRef]

20. Oboh, M.A.; Ndiaye, D.; Antony, H.A.; Badiane, A.S.; Singh, U.; Ali, N.A.; Bharti, P.K.; Das, A. Status of Artemisinin Resistance in Malaria Parasite Plasmodium falciparum from Molecular Analyses of the Kelch13 Gene in Southwestern Nigeria. BioMed Res. Int. 2018, 2018, 1-5. [CrossRef]

21. Cheesbrough, M. District Laboratory Practice in Tropical Countries by Monica Cheesbrough. In District Laboratory Practice in Tropical Countries; Cambridge University Press: Cambridge, UK, 2006.

22. Ohrt, C.; Purnomo; Sutamihardja, M.A.; Tang, D.; Kain, K. Impact of Microscopy Error on Estimates of Protective Efficacy in Malaria? Prevention Trials. J. Infect. Dis. 2002, 186, 540-546. [CrossRef] [PubMed]

23. Echeverry, D.F.; Deason, N.A.; Davidson, J.; Makuru, V.; Xiao, H.; Niedbalski, J.; Kern, M.; Russell, T.L.; Burkot, T.R.; Collins, F.H.; et al. Human malaria diagnosis using a single-step direct-PCR based on the Plasmodium cytochrome oxidase III gene. Malar. J. 2016, 15, 128. [CrossRef] [PubMed]

24. Hall, T.A. BioEdit: A user-friendly biological sequence alignment editor and analysis program for Windows 95/98/NT. In Proceedings of the Nucleic Acids Symposium Series; Oxford University Press: Oxford, UK, 1998; Volume 41, pp. 95-98.

25. Librado, P.; Rozas, J. DnaSP v5: A software for comprehensive analysis of DNA polymorphism data. Bioinformatics 2009, 25, 1451-1452. [CrossRef] [PubMed]

26. Tamura, K.; Stecher, G.; Peterson, D.; Filipski, A.; Kumar, S. MEGA6: Molecular Evolutionary Genetics Analysis version 6.0. Mol. Boil. Evol. 2013, 30, 2725-2729. [CrossRef]

27. Laminou, I.M.; Lamine, M.M.; Arzika, I.; Mahamadou, B.; Gora, D.; Dieye, A. Detection of Plasmodium falciparum K13 Propeller A569G Mutation after Artesunate-amodiaquine Treatment Failure in Niger. J. Adv. Boil. Biotechnol. 2018, 18,1-8. [CrossRef]

28. Dama, S.; Niangaly, H.; Ouattara, A.; Sagara, I.; Sissoko, S.; Traore, O.B.; Bamadio, A.; Dara, N.; Djimde, A.; Alhousseini, M.L.; et al. Reduced ex vivo susceptibility of Plasmodium falciparum after oral artemether-lumefantrine treatment in Mali. Malar. J. 2017, 16, 59. [CrossRef] [PubMed]

29. Kamau, E.; Campino, S.; Amenga-Etego, L.; Drury, E.; Ishengoma, D.S.; Johnson, K.; Mumba, D.; Kekre, M.; Yavo, W.; Mead, D.; et al. K13-Propeller Polymorphisms in Plasmodium falciparum Parasites from Sub-Saharan Africa. J. Infect. Dis. 2014, 211, 1352-1355. [CrossRef] [PubMed]

30. Boussaroque, A.; Fall, B.; Madamet, M.; Wade, K.A.; Fall, M.; Nakoulima, A.; Fall, K.B.; Dionne, P.; Benoit, N.; Diatta, B.; et al. Prevalence of anti-malarial resistance genes in Dakar, Senegal from 2013 to 2014. Malar. J. 2016, 15, 347. [CrossRef]

31. Ouattara, A.; Bjorkman, A.; Kone, A.; Adams, M.; Diallo, N.; Dara, A.; Maiga, A.W.; Takala-Harrison, S.; Fofana, B.; Plowe, C.V.; et al. Polymorphisms in the K13-Propeller Gene in Artemisinin-Susceptible Plasmodium falciparum Parasites from Bougoula-Hameau and Bandiagara, Mali. Am. J. Trop. Med. Hyg. 2015, 92, 1202-1206. [CrossRef] [PubMed] 
32. Somé, A.; Sorgho, H.; Zongo, I.; Bazié, T.; Nikiéma, F.; Sawadogo, A.; Zongo, M.; Compaore, Y.D.; Ouedraogo, J.B. Polymorphisms inK13, pfcrt, pfmdr1, pfdhfr, andpfdhpsin parasites isolated from symptomatic malaria patients in Burkina Faso. Parasite 2016, 23, 60. [CrossRef] [PubMed]

33. Olasehinde, G.; Ojurongbe, D.; Akinjogunl, O.; Egwari, L.; Adeyeba, A. Prevalence of Malaria and Predisposing Factors to Antimalarial Drug Resistance in Southwestern Nigeria. Res. J. Parasitol. 2015, 10, 92-101. [CrossRef]

34. Kalu, K.M.; Obasi, N.A.; Nduka, F.O.; Oko, M.O. Prevalence of Malaria Parasitaemia in Umuchieze and Uturu Communities of Abia State, Nigeria. Asian J. Epidemiol. 2012, 5, 95-102. [CrossRef]

(C) 2020 by the authors. Licensee MDPI, Basel, Switzerland. This article is an open access article distributed under the terms and conditions of the Creative Commons Attribution (CC BY) license (http://creativecommons.org/licenses/by/4.0/). 